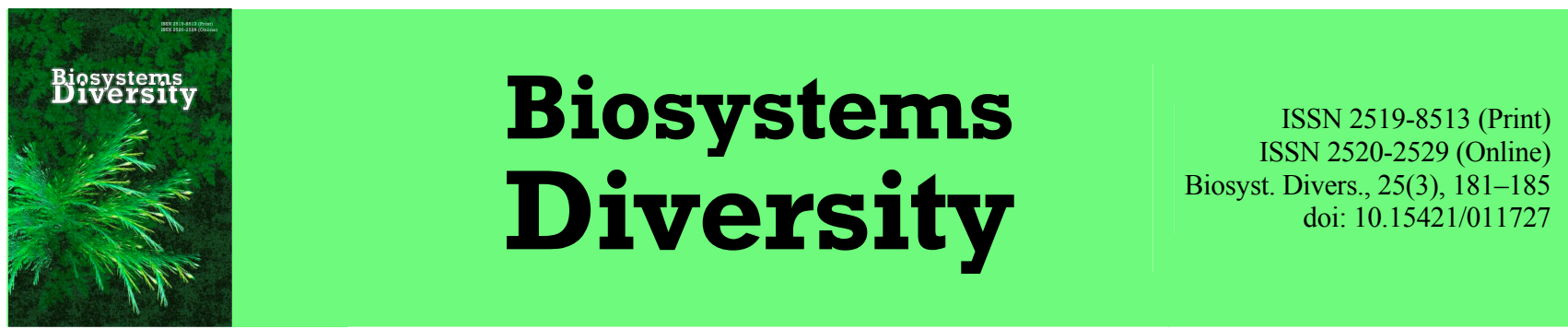

\title{
The usage of sulfide and thiosulfate ions by purple non-sulfur bacteria Rhodopseudomonas yavorovii
}

\author{
O. V. Tarabas, S. O. Hnatush, O. M. Moroz, V. O. Vasylechko, \\ G. V. Gryshchouk, G. I. Zvir, S. Y. Komplikevych
}

Ivan Franko National University of Lviv, Lviv, Ukraine

Article info

Received 12.06.2017

Received in revised form 17.07.2017

Accepted 20.07.2017

Ivan Franko National University of Lviv, Hrushevsky Str., 4 Lviv, 79005, Ukraine.

Tel.: +38-096-784-60-25.

E-mail: otarabas@gmail.com
Tarabas, O. V., Hnatush, S. O., Moroz, O. M., Vasylechko, V. O., Gryshchouk, G. V., Zvir, G. I., \& Komplikevych, S. Y. (2017). The usage of sulfide and thiosulfate ions by purple non-sulfur bacteria Rhodopseudomonas yavorovii. Biosystems Diversity, 25(3), 181-185. doi:10.15421/011727

The article covers the patterns of oxidation of sulfide and thiosulfate ions by bacteria Rhodopseudomonas yavorovii Ya-2016 under different cultivation conditions. In the environments with 1.4-5.6 $\mathrm{mM} \mathrm{Na}_{2} \mathrm{~S}_{2} \mathrm{O}_{3}, R$. yavorovii $\mathrm{Ya}-2016$ bacteria accumulated biomass of 1.4-1.6 g/l, which was higher than biomass $(1.2-0.6 \mathrm{~g} / \mathrm{l})$ accumulated by the bacteria with the same concentrations of $\mathrm{Na}_{2} \mathrm{~S} \times 9 \mathrm{H}_{2} \mathrm{O}$. The efficiency of oxidation of $1.4,2.8,5.6 \mathrm{MM}$ sulfide- and thiosulfateions as donors of electrons by the bacteria equaled $97.4,42.6,18.7$ and $68.8,28.0,3.7 \%$, relatively. As a result bacteri' oxidation of $1.4 \mathrm{MM}$ hydrogen sulfide and sodium thiosulphate in the environment caused accumulation of $0.13-$ $1.30 \mathrm{MM}$ sulfate-ions, and the element sulfur became an intermediate metabolite in the environment with $\mathrm{Na}_{2} \mathrm{~S} \times 9 \mathrm{H}_{2} \mathrm{O}$. R. yavorovii Ya-2016 bacteria are capable of using sulfate-ions as a single source of sulfate at increase in photptrophs. In the environment with $2.5 \mathrm{mM}$ sulfate-ions concentration the bacteria biomass was $1.4 \mathrm{~g} / \mathrm{l}$, the bacteria assimilated $17.7 \%$ of sulfates. Because purple non-sulfur bacteria R. yavorovii Ya-2016 are capable of using sulfide-ions as donors of electrons of anoxygenic photosynthesis and using sulfate-ions as a single source of sulfate, they could be successfully used in the technologies of remediating the environment from compounds of sulfur.

Keywords: purple non-sulfur bacteria; sodium thiosulfate; elemental sulfur; hydrogen sulfide

\section{Використання сульфід- та тіосульфат-іонів пурпуровими несірковими бактеріями Rhodopseudomonas yavorovii}

\author{
О. В. Тарабас, С. О. Гнатуш, О. М. Мороз, В. О. Василечко, Г. В. Грищук, Г. І. Звір, С. Я. Комплікевич
}

Львівський національний університет імені Івана Франка, Львів, Украӥна

Охарактеризовано закономірності окиснення сульфід- та тіосульфат-іонів фототрофними пурпуровими несірковими бактеріями Rhodopseudomonas yavorovii Ya-2016. У середовищах з 1,4-5,6 мM Na $2 \mathrm{~S}_{2} \mathrm{O}_{3}$ бактерії $R$. yavorovii Үа-2016 нагромаджували біомасу 1,4 1,6 г/л, яка перевищувала біомасу $\left(1,2-0,6\right.$ г/л), нагромаджену бактеріями 3 аналогічними концентраціями $\mathrm{Na}_{2} \mathrm{~S} \times 9 \mathrm{H}_{2} \mathrm{O}$. Ефективність окиснення 1,4, 2,8, 5,6 мМ сульфід- та тіосульфат-іонів як донорів електронів бактеріями становила 97,4, 42,6, 18,7 та 68,8, 28,0, 3,7\%, відповідно. В результаті окиснення бактеріями 1,4 мМ гідроген сульфіду та натрій тіосульфату у середовищі нагромаджується $0,13-$ 1,30 мМ сульфат-іонів, а елементна сірка - проміжний метаболіт у середовищі $3 \mathrm{Na}_{2} \mathrm{~S} \times 9 \mathrm{H}_{2} \mathrm{O}$. R. yavorovii Үа-2016 здатні використовувати сульфат-іони як єдине джерело сульфуру за фототрофного росту. За концентрації 2,5 мМ сульфат-іонів у середовищі біомаса бактерій була 1,4 г/л, бактерії асимілювали 17,7\% сульфатів. Оскільки пурпурові несіркові бактерії $R$. yavorovii Үа-2016 здатні використовувати сульфідіони як донори електронів аноксигенного фотосинтезу та сульфат-іони як єдине джерело сульфуру, вони можуть бути успішно використані у технологіях ремедіації довкілля від сполук сульфуру.

Ключові слова: пурпурові несіркові бактерії; натрій тіосульфат; елементна сірка; гідроген сульфід

Вступ

Фотосинтезувальні пурпурові бактерії здатні фіксувати карбон діоксид, молекулярний азот і окиснювати відновлені сполуки сульфуру, тому вони відіграють важливу роль у глобальних біогеохімічних циклах карбону, нітрогену і сульфуру (Poretsky, 2003). Пурпурові несіркові бактерії (ПНБ) та пурпурові сіркові бактерії (ПСБ) здійснюють аноксигенний фотосинтез в анаеробних умовах. У цьому процесі екзогенними донорами електронів можуть бути сульфіди, тіосульфати, тетратіонати, молекулярна сірка, молеку- лярний водень у фотолітотрофів і органічні речовини у фотоорганотрофів (Kozlova et al., 2008). ПНБ - мікроорганізми, що належать до класів Alphaproteobacteria (види родів Rhodospirillum, Rhodocista та ін. родини Acetobacteraceae; види родів Rhodobacter, Rhodovulum та ін. родини Rhodobacteraeae; види родів Rhodopseudomonas та ін. родини Bradyrhizobiaceae; види роду Rhodomicrobium родини Hyphomicrobiaceae та види роду Rhodobium родини Rhodobiaceae) тa Betaproteobacteria (Ghosh and Dam, 2009).

Пурпурові бактерії можуть рости фотогетеротрофно, фотоавтотрофно або хемогетеротрофно залежно від забезпеченості кис- 
нем, наявності джерела карбону $\left(\mathrm{CO}_{2}\right.$ для автотрофного росту, органічних сполук для гетеротрофного росту), а також джерела світла (необхідне для фототрофного росту).

Термін «несіркові» виник тому, що вважали, що ПНС бактерії не використовують гідроген сульфід як донор електронів в умовах фотоавтотрофного росту. Проте вони можуть використовувати сульфід-іон як донор електронів, але не за таких високих концентрацій як ПСБ (Basak and Das, 2007). ПНБ також можуть використовувати тіосульфат як донор електронів у процесі аноксигенного фотосинтезу. На молекулярно-генетичному та біохімічному рівнях окиснення тіосульфату найкраще описане на прикладі пурпурових сіркових бактерій Allochromatium vinosum, у яких є два різні шляхи окиснення цієї сполуки. У першому - два аніони тіосульфату окиснюються мікроорганізмами до тетратіонату. У другому шляху - периплазматичний мультиензимний Sox комплекс бере участь у повному окисненні тіосульфату до сульфату. $A$. vinosum окиснює тіосульфат двома шляхами одночасно. Багато видів пурпурових сіркових і несіркових бактерій і навіть декілька видів зелених фотосинтезувальних бактерій здатні засвоювати та відновлювати сульфат-іони за відсутності відновлених сполук сульфуру (Hallenbeck, 2017).

Гідроген сульфід негативно впливає на живі організми (Galushka et al., 2012). Застосування методів біологічного очищення стічних вод від токсичних сполук сульфуру економічно доцільніше. Використання фізико-хімічних методів потребує значних витрат, тому їх застосовують для попереднього очищення (Dzhigireji, 2004). Мета нашого дослідження - виявити закономірності використання сульфід- та тіосульфат-іонів пурпуровими несірковими бактеріями Rhodopseudomonas yavorovii Yа-2016, виділеними нами з води озера Яворівське, для оцінювання потенційної можливості їх застосування у технологіях очищення від сполук сульфуру. Відомо (Vasylechko and Gryshhuk, 2008; Moroz et al., 2008), що у водоймах Яворівського сіркового родовища, зокрема, у воді новоутвореного Яворівського озера, наявний високий вміст гідроген сульфіду.

\section{Матеріал і методи досліджень}

Об'єкт дослідження - культура пурпурових несіркових бактерій Rhodopseudomonas yavorovii Үа-2016, виділена 3 води озера Яворівське, ідентифікована на кафедрі мікробіології ЛНУ імені Івана Франка (Tarabas et al., 2017).

Бактерії вирощували анаеробно за температури $+27 \ldots+30{ }^{\circ} \mathrm{C}$ та інтенсивності освітлення 200 лк у пробірках об'ємом 25 мл. Пробірки повністю заповнювали середовищем і закривали пластиковими корками на закрутку. Анаеробні умови забезпечували кип'ятінням і швидким охолодженням середовища культивування, що зумовлює зменшення в ньому конщентрації розчиненого кисню (Postgate, 1985). Мікроорганізми культивували упродовж 13 діб у модифікованому середовищі АТСС № 1449 такого складу (г/л): амоній хлорид - 0,4, калій дигідрофосфат - 0,6, кальцій хлорид дигідрат - 0,05, магній сульфат гептагідрат - 0,320, натрій ацетат тригідрат - 0,816. $\mathrm{pH}$ середовища 7,0-7,3. Початкова концентрація клітин була 0,2 г/л.

Для дослідження впливу сульфід- та тіосульфат-іонів на ріст клітин у середовище культивування вносили різні концентрації $(1,4,2,8,5,6$ мM) натрій сульфіду наногідрату та натрій тіосульфату. Замість магній сульфат гептагідрату у середовище культивування вносили 0,261 г/л магній хлориду. Щоб дослідити використання сульфат-іонів як єдиного джерела сульфуру, у модифіковане середовище АТСС № 1449 вносили різні концентрації $(0,5,1,2$, $2,5,3,4,5$ мМ) магній сульфату гептагідрату. Інтенсивність освітлення вимірювали люксметром Ю-116.

Біомасу вимірювали турбідиметрично з використанням фотоелектроколориметра КФК-3 ( $\lambda=660 \mathrm{HM})$. Для екстракції сірки клітини осаджували на нітроцелюлозних фільтрах (діаметр пор $0,4 \mu \mathrm{m})$. Позаклітинну сірку екстрагували етанолом, а її вміст визначали спектрофотометрично 3 використанням спектрофотометра СФ-46 ( $\lambda=260$ нм) за методикою Ван Гемердена, застосову- ючи калібрувальну криву (Gudz et al., 2014). Концентрацію гідроген сульфіду визначали спектрофотометрично $(\lambda=665$ нм) за утворенням метиленової сині з використанням $n$-амінодиметиланілін дигідрохлориду (Sugiyama, 2002). Вміст сульфат-іонів визначали турбідиметрично ( $\lambda=520$ нм) після їх осадження барій хлоридом. Для стабілізації суспензії використовували гліцерин (Росhvy. Metod opredelenija ionov sulfata v vodnoji vyiityazhke). Концентрацію тіосульфат-іонів визначали йодометричним методом, в основі якого є реакція:

$$
2 \mathrm{~S}_{2} \mathrm{O}_{3}{ }^{2-}+\mathrm{I}_{2}=\mathrm{S}_{4} \mathrm{O}_{6}{ }^{2-}+2 \mathrm{I}^{-}
$$

Для встановлення точки еквівалентності брали розчин крохмалю як індикатор (Lur'e and Rybnikova, 1974).

Статистичну обробку результатів досліджень та побудову графіків проводили за допомогою програми Microsoft Excel 2016. Результати представлені як середнє значення з поправкою на стандартну похибку $(\mathrm{M} \pm \mathrm{SE})$. Достовірність даних і різниці між ними оцінювали за коефіцієнтом Стьюдента. Достовірною вважали різницю за рівня значимості $\mathrm{P}<0,05$.

\section{Результати}

Сульфур у відновлених формах має високу реакційну здатність. Сульфати або сульфіди у воді та грунті, а також діоксид сульфуру в атмосфері становлять основну частину сульфуру в природі (Hallenbeck, 2017). Сульфур входить до складу білків (0,8$2,4 \%$ ), вітамінів, глікозидів, коферментів тощо. $\mathrm{SO}_{4}^{2-}-$ окиснена форма сульфуру, що використовується як джерело сульфуру рослинами та мікроорганізмами (Grabovich, 1999). $\mathrm{SO}_{4}^{2-}$ у разі асиміляції мікроорганізмами відновлюється до сульфід-іона, що включається у процеси біосинтезу (асиміляційна сульфатредукція) і не накопичується у довкіллі (Kozlova et al., 2008).

Виділені нами бактерії $R$. yavorovii Үa-2016 здатні споживати сульфат-іони як єдине джерело сульфуру. За вмісту в модифікованому середовищі АТСС № 1449 2,5 мМ сульфат-іонів біомаса R. yavorovii Үа-2016 була 1,4 г/л, що на 35,2\% більше, ніж біомаса бактерій, культивованих у середовищі, яке містило $1 \mathrm{MM} \mathrm{MgSO}_{4} \times$ $7 \mathrm{H}_{2} \mathrm{O}$ (рис. 1). Збільшення вмісту магній сульфату гептагідрату до 5 мМ спричиняло зниження нагромадження біомаси дослідженими мікроорганізмами.

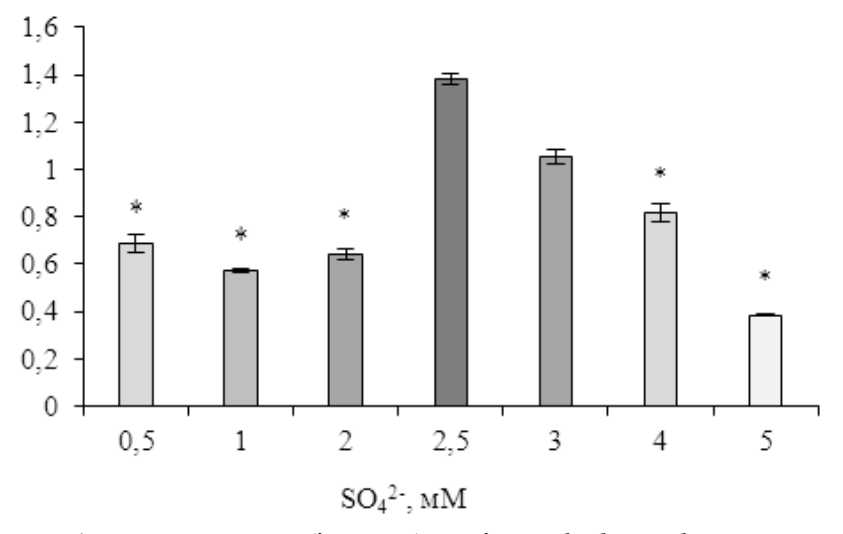

Pис. 1. Нагромадження біомаси бактеріями Rhodopseudomonas yavorovii Үa-2016 на 13-ту добу росту за впливу різних концентрацій $\mathrm{MgSO}_{4} \times 7 \mathrm{H}_{2} \mathrm{O}$; контроль - середовище $32,5 \mathrm{MM} \mathrm{MgSO}_{4} \times 7 \mathrm{H}_{2} \mathrm{O}$

За росту у середовищі з 2,5 мМ сульфат-іонів бактерії асимілюють 17,7\% сульфатів на 13-ту добу (рис. 2). Експоненційна фаза росту триває до 13-ї доби культивування за відсутності в середовищі відновлених сполук сульфуру, на відміну від росту клітин у середовищі з натрій сульфідом наногідратом і натрій тіосульфатом (рис. $3 a$, б). За фототрофного росту ці бактерії використовують натрій сульфід наногідрат і натрій тіосульфат як донори електронів, на відміну від Rhodopseudomonas rhenobacensis та Rh. cryptolactis (Imhoff, 2005).

Найбільшу біомасу (1,2 г/л) бактерії нагромаджували на 10-ту добу росту у середовищі з $1,4 \mathrm{MM} \mathrm{Na} 2 \mathrm{~S} \times 9 \mathrm{H}_{2} \mathrm{O}$. Збільшення кон- 
центрації $\mathrm{Na}_{2} \mathrm{~S} \times 9 \mathrm{H}_{2} \mathrm{O}$ у середовищі до 2,8 і 5,6 мМ спричиняло зниження нагромадження біомаси бактеріями $R$. yavorovii Ya-2016. За концентрації 5,6 мM Na $2 \mathrm{~S} \times 9 \mathrm{H}_{2} \mathrm{O}$ у середовищі нагромадження біомаси бактерій знижувалося вдвічі, порівняно 3 контролем (рис. 3a). За конщентрації у середовищі 1,4 мM Na $2 \mathrm{~S}_{2} \mathrm{O}_{3}$ біомаса клітин $R$. yavorovii Ya-2016 була 1,4 г/л, тоді як за концентрації 2,8 мМ натрій тіосульфату - 1,5 г/л. За підвищення вмісту $\mathrm{Na}_{2} \mathrm{~S}_{2} \mathrm{O}_{3}$ до 5,6 мМ біомаса бактерій зростала до 1,6 г/л (рис. 3б). Максимальний приріст біомаси спостерігали на 10-13-ту добу культивування. На відміну від сульфід-іонів, тіосульфат-іони стимулювали ріст бактерій.

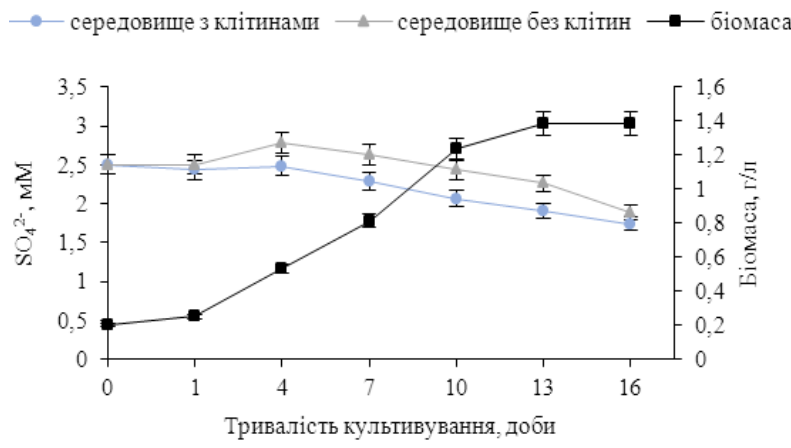

Рис. 2. Нагромадження біомаси бактеріями Rhodopseudomonas yavorovii Үa-2016 за використання 2,5 мМ сульфат-іонів
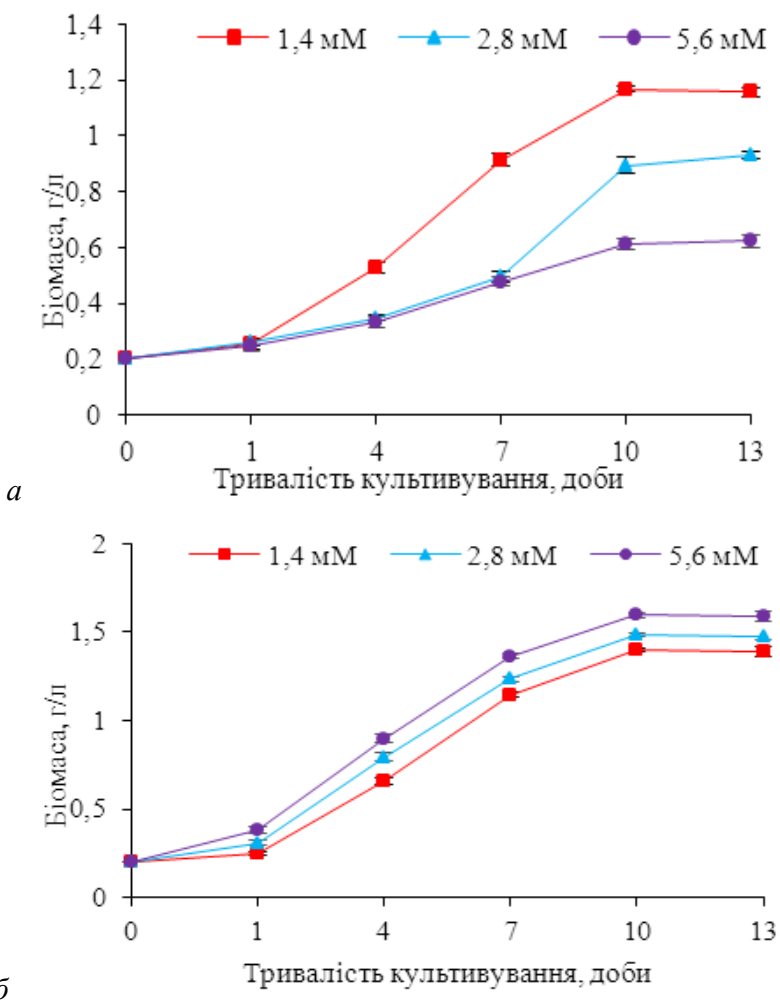

Рис. 3. Нагромадження біомаси бактеріями Rhodopseudomonas yavorovii Ya-2016 за внесення у середовище різних концентрацій $\mathrm{Na}_{2} \mathrm{~S} \times 9 \mathrm{H}_{2} \mathrm{O}(a)$ та $\mathrm{Na}_{2} \mathrm{~S}_{2} \mathrm{O}_{3}$ (б); контроль - середовище 3 $1,4 \mathrm{MM} \mathrm{Na}_{2} \mathrm{~S} \times 9 \mathrm{H}_{2} \mathrm{O}$ чи $\mathrm{Na}_{2} \mathrm{~S}_{2} \mathrm{O}_{3}$

Деякі види фототрофних пурпурових несіркових бактерій можуть споживати гідроген сульфід і тіосульфати як донори електронів (Imhoff, 2005). Бактерії $R$. yavorovii Ya-2016 у середовищі з 1,4 мМ гідроген сульфіду знижують його вміст на 97,4\%. За більших концентрацій у середовищі гідроген сульфід поглинається бактеріями менш інтенсивно, зокрема, за концентрації 2,8 мМ бактерії спожили 42,6\% гідроген сульфіду, 5,6 мМ - лише $18,7 \%$ (рис. $4 a$ ). Ймовірно, сповільнення окиснення бактеріями гідроген сульфіду за високих концентрацій у середовищі відбувається унаслідок пригнічення у них фотосинтетичних і ростових процесів. Можливо, гідроген сульфід, взаємодіючи з металовмісними білками та іншими клітинними метаболітами, пошкоджує структуру та функції світлозбиральних пігментів, фотохімічних реакційних центрів і фотосинтетичних електронотранспортних систем у клітинах фототрофних бактерій (Julian et al., 2005). У середовищі 3 1,4 мМ тіосульфат-іонів бактерії знижують їх вміст на $68,8 \%$ на 10 -ту добу. За більших концентрацій у середовищі тіосульфат-іони поглинались бактеріями менш інтенсивно, зокрема, за концентрації 2,8 мМ бактерії спожили $28,0 \%$ тіосульфатіонів, 5,6 мМ - лише $3,7 \%$ (рис. 4 ).
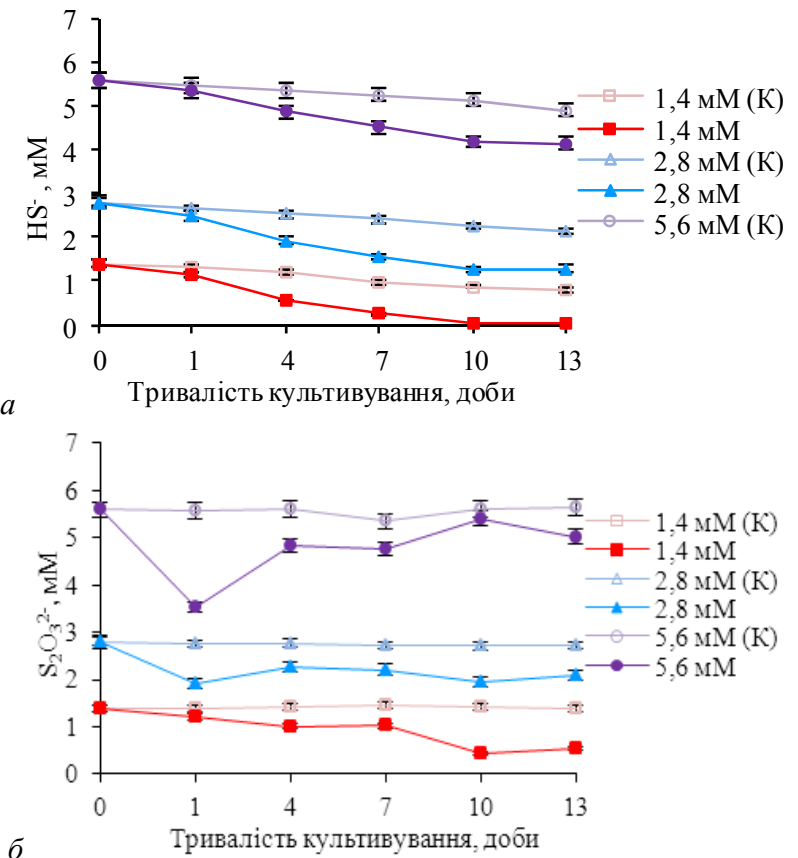

Рис. 4. Використання гідроген сульфіду $(a)$ та натрій тіосульфату (б) бактеріями Rhodopseudomonas yavorovii Ya-2016; контроль - середовище $31,4 \mathrm{MM} \mathrm{Na}_{2} \mathrm{~S} \times 9 \mathrm{H}_{2} \mathrm{O}$ чи $\mathrm{Na}_{2} \mathrm{~S}_{2} \mathrm{O}$

У результаті окиснення бактеріями гідроген сульфіду за його вмісту 1,4, 2,8 та 5,6 мМ у середовищі нагромаджувалось 0,13 , 0,12 та 0,11 мМ сульфат-іонів відповідно. Елементна сірка нагромаджувалась поза клітинами в невеликих кількостях: 0,009, 0,007 та 0,006 г/г сухої ваги клітин, відповідно, на 13-ту добу культивування (рис. $5 a$ ). У результаті дослідження закономірностей використання натрій тіосульфату R. yavorovii Үa-2016 встановили, що бактерії використовують останній як донор електронів під час аноксигенного фотосинтезу. Протягом 13 діб культивування в результаті окиснення тіосульфат-іонів за їх вихідних концентрацій 1,4, 2,8, 5,6 мМ у середовищі нагромаджувались сульфат-іони, концентрація яких на 10-ту добу культивування була $1,30,0,75$, 0,44 мМ відповідно (рис. 5б). R. yavorovii Үа-2016 споживають сульфат-іони у процесах асиміляції, про що свідчить крива росту бактерій (рис. 3б). Елементна сірка не нагромаджувалась поза клітинами за росту бактерій у середовищі з натрій тіосульфатом.

\section{Обговорення}

Аналізуючи отримані дані, варто зазначити, що $R$. yavorovii Ya-2016, як і Rhodopseudomonas globiformis та Rh. palustris, використовують сульфат-іони як єдине джерело сульфуру (Imhoff, 1981; Imhoff et al., 2005). R. globiformis (Imhoff et al., 1981) здатні рости у середовищі з концентрацією сульфат-іонів нижче 1 мМ. На відміну від цих бактерій, $R$. yavorovii Үа-2016 ростуть у середовищі 3 вищою у 2,5 раза концентрацією сульфат-іонів. Rh. sulfoviridis (Neutzling and Truper, 1982) не здатні споживати сульфатіони як єдине джерело сульфуру, порівняно з R. yavorovii Ya-2016. 
Ріст $R$. sulfoviridis забезпечується наявністю у середовищі культивування сульфід-, тіосульфат-іонів, елементної сірки та цистеїну.
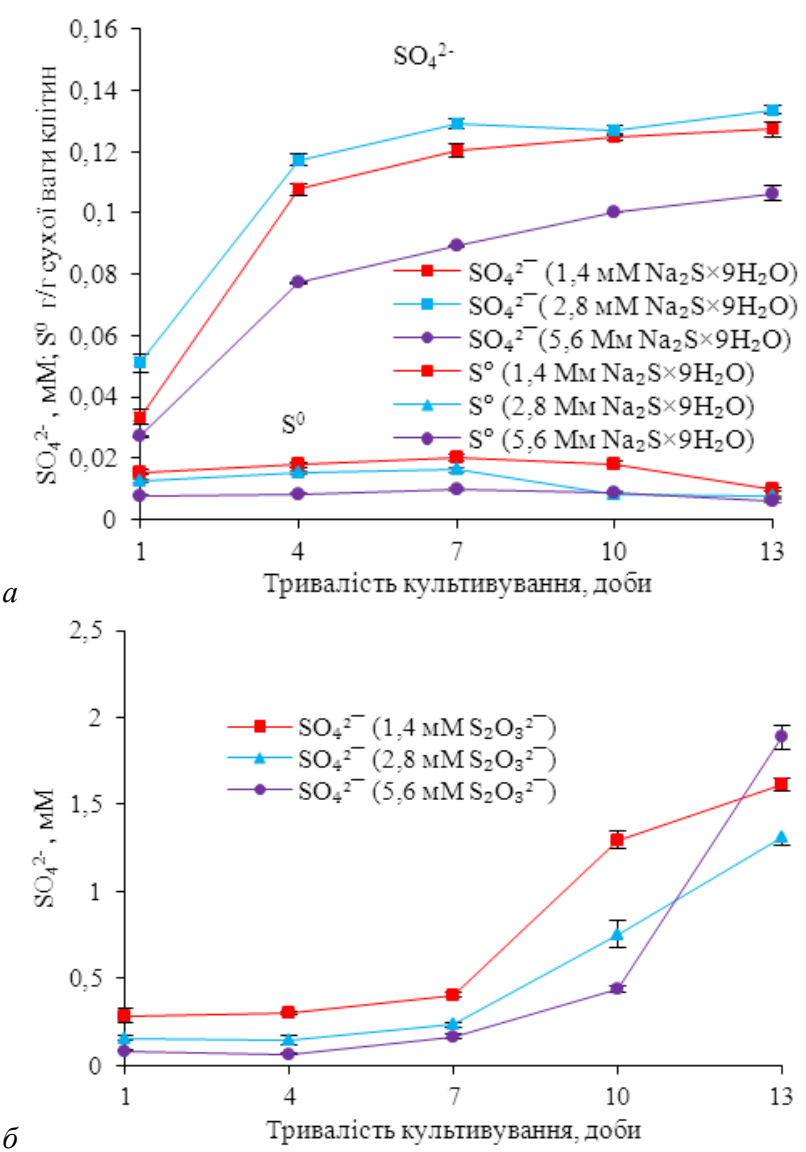

Рис. 5. Утворення сульфат-іонів і елементної сірки бактеріями Rhodopseudomonas yavorovii Ya-2016 у середовищі $3 \mathrm{Na}_{2} \mathrm{~S} \times 9 \mathrm{H}_{2} \mathrm{O}(a)$ i $\mathrm{Na}_{2} \mathrm{~S}_{2} \mathrm{O}_{3}$ (б); контроль - середовище $31,4 \mathrm{MM} \mathrm{Na}_{2} \mathrm{~S} \times 9 \mathrm{H}_{2} \mathrm{O}$ чи $\mathrm{Na}_{2} \mathrm{~S}_{2} \mathrm{O}_{3}$

Пурпурові несіркові бактерії, зокрема, представники порядків Rhodocyclales i Burkholderiales класу Betaproteobacteria, не використовують відновлені сполуки сульфуру як донори електронів аноксигенного фотосинтезу. Сульфіди пригнічують ріст цих мікроорганізмів за низьких концентрацій (Imhoff et al., 2005). Серед пурпурових несіркових бактерій (порядки Rhodospirillales, Rhizobiales, Rhodobacterales класу Alphaproteobacteria) є види, здатні поглинати відновлені сполуки сульфуру. Ці мікроорганізми значно відрізняються за проміжними та кінцевими продуктами окиснення сполук сульфуру. У Rhodopseudomonas capsulatus i Rhodospirillum rubrum сірка поза клітинами - кінцевий продукт окиснення сульфідів. Проте у видів роду Rhodovulum, бактерій $R$. palustris, Blastochloris sulfoviridis сульфати - кінцевий продукт окиснення сульфідів (Frigaard and Dahl, 2009). Деякі види, зокрема, Rhodoplanes roseus i Rh. elegans як донор електронів споживають лише тіосульфати (Hiraishi and Ueda, 1994). Пурпурові несіркові бактерії R. yavorovii Ya-2016 здатні використовувати останні як донори електронів, окиснюючи їх до сульфатів. $R$. adriatica окиснює сульфіди до елементної сірки та перетворює їх частково до сульфатів, тоді як тіосульфати окиснюються до сульфатів без нагромадження сірки як проміжного продукту (Neutzling et al., 1984). Варто підкреслити, що R. yavorovii Үа-2016 окиснюють сульфід до сульфатів як кінцевого продукту з утворенням елементної сірки як проміжного метаболіту.

\section{Висновки}

Виділені та ідентифіковані нами бактерії $R$. yavorovii Yа-2016 здатні використовувати сульфат-іони як єдине джерело сульфуру за фототрофного росту. Зниження концентрацій сульфід- та тіосульфат-іонів у середовищі культивування свідчить, що пурпурові несіркові бактерії здатні використовувати останні як донори електронів у процесі аноксигенного фотосинтезу. У середовищі $з$ 1,4 мМ сульфід- та тіосульфат-іонів досліджені бактерії знижують ïх вміст на 97,4\% і 68,8\% відповідно. У результаті окиснення бактеріями гідроген сульфіду елементна сірка - проміжний метаболіт. Здатність фототрофних пурпурових несіркових бактерій окиснювати гідроген сульфід та використовувати сульфат-іони як єдине джерело сульфуру робить їх перспективними об'єктами в технологіях біоремедіації грунтів та води.

\section{References}

Basak, N., \& Das, D. (2007). The prospect of purple non-sulfur (PNS) photosynthetic bacteria for hydrogen production: The present state of the art. World Journal of Microbiology and Biotechnology, 23, 31-42.

Dzhigireji, V. S. (2004). Ekologija ta ohorona navkolyshn'ogo seredovyshha [Ecology and environment]. Znannya, Kyiv (in Ukrainian).

Frigaard, N.-U., \& Dahl, C. (2009). Sulfur metabolism in phototrophic sulfur bacteria. Advances in Microbial Physiology, 54, 103-200.

Galushka, A. A., Peretjatko, T. B., \& Gudz', S. P. (2012). Vplyv gidrogen sul'fidu na bilkovyj sklad klitynnoi' stinky drizhdzhiv Saccharomyces cerevisiae [Influence of hydrogen sulfide on the composition of cell wall proteins of Saccharomyces cerevisiae yeast]. Biologichni Studii', 6(3), 125-134 (in Ukrainian).

Ghosh, W., \& Dam, B. (2009). Biochemistry and molecular biology of lithotrophic sulfur oxidation by taxonomically and ecologically diverse bacteria and archaea. FEMS Microbiology Reviews, 33(6), 999-1043.

Grabovich, J. M. (1999). Uchastie prokariot u kgugovorote seri [The participation of prokaryotes in sulfur turnover]. Sorosovskij Obrazovatel'nij Zhurnal, 12, $16-21$ (in Russian).

Gudz, S. P., Hnatush, S. O., Yavorska, G. V., \& Bilinska, I. S., Borsukevych, B. M. (2014). Praktykum z mikrobiologii' [Workshop on microbiology]. L'vivs'kyj Nacional'nyj Universytet imeni Ivana Franka, Lviv (in Ukrainian).

Hallenbeck, P. C. (2017). Modern topics in the phototrophic prokaryotes. Springer International Publishing AG.

Hiraishi, A., \& Ueda, Y. (1994). Rhodoplanes gen. nov., a new genus of phototrophic bacteria including Rhodopseudomonas rosea as Rhodoplanes roseus comb. nov. and Rhodoplanes elegans sp. nov. International Journal of Systematic Bacteriology, 44, 665-673.

Imhoff, J. F., Then, J., Hashwa, F., \& Truper, H. (1981). Sulfate Assimilation in Rhodopseudomonas globiformis. Archives of Microbiology, 130, $234-237$.

Imhoff, J. F., Hiraishi, A., \& Suling, J. (2005). Bergey's Manual of Systematic Bacteriology. The Proteobacteria. Part C. The Alpha-, Beta-, Delta-, and Epsilonproteobacteria. Edited by Garrity, G. M, Staley, J. T., Krieg, N. R., \& Brenner, D. J. Springer, USA.

Julian, D., April, K. L., \& Patel, S. (2005). Mitochondrial depolarization following hydrogen sulfide exposure in erythrocytes from a sulfidetolerant marine invertebrate. Journal of Experimental Biology, 208(21), $4109-4122$.

Kozlova, I. P., Radchenko, O. S., Stepura, L. G., \& Kondratjuk, T. O. (2008). Geohimichna dijal'nist' mikroorganizmiv ta i'i' prykladni aspekty [Geochemical activity of microorganisms and its practical aspects]. Naukova Dumka, Kyiv (in Ukrainian).

Lur'e, J. J., \& Rybnikova, A. I. (1974). Himicheskij analiz proizvodstvennyh stochnyh vod [Chemical analysis of industrial wastewater]. Himija, Moscow (in Russian).

Moroz, O. M., Kolisnyk, J. I., Podoprygora, O. I., Klym, I. R., Gudz', S. P., Borsukevych, B. M., \& Gnatush S. O. (2008). Mikroflora vody ozera "Javorivs'ke" [Microflora of the lake "Yavorivske" water]. Naukovyj Visnyk Uzhgorods'kogo Universytetu. Serija Biologichna, 24, 131-138 (in Ukrainian).

Neutzling, O., Imhoff, J. F., \& Truper, H. G. (1984). Rhodopseudomonas adriati$c a$ sp. nov., a new species of the Rhodospirillaceae, dependent on reduced sulfur compounds. Archives of Microbiology, 137, 256-261.

Neutzling, O., \& Truper, H. (1982). Assimilatory sulfur metabolism in Rhodopseudomonas sulfoviridis. Archives of Microbiology, 33, 145-148.

Pochvyii. Metod opredelenie ionov sulfata v vodnoji vyiityazhke [Soil. Method for determination of sulfate ions in water extract]. GOST 26426-85. Izdatelstvo Standartov, Moscow (in Russian).

Poretsky, R. S. (2003). Finding a niche: The habits and habitats of purple nonsulfur bacteria. Microbial Diversity Athens, GA 30602.

Postgate, J. R. (1985). The sulfate-reducing bacteria. 2nd ed. Cambridge University Press, Cambridge. 
Sugiyama, M. (2002). Reagent composition for measuring hydrogen sulfide and method for measuring hydrogen sulfide. United States Patent No 6340596.

Tarabas, O. V., Gnatush, S. O., Ostash, B. O., Mutenko, G. V., \& Koshla, O. V. (2017). Identyfikacija purpurovyh nesirkovyh bakterij Rhodopseudomonas $s p$. Ya-2016 [Identification of purple non-sulfur bacteria of Rhodopseudomonas sp. Ya-2016]. Visnyk L'vivs'kogo Universytetu. Serija Biologichna, 75, 140-145 (in Ukrainian).
Vasylechko, V. O., \& Gryshhuk, G. V. (2008). Himiko-analitychne doslidzhennja vodojmyshh Javorivs'kogo sirkovogo rodovyshha. Materialy V Mizhnarodnoi' naukovo-praktychnoi' konferencii' 'Resursy pryrodnyh vod Karpats'kogo regionu" [Chemical and analytical study of water reservoirs of Yavorivsky sulfur deposit. Materials of the 5th International Scientific and Practical Conference: "Resources of the Natural Waters of the Carpathian Region]. LvCNTEI, L'viv,74-84 (in Ukrainian). 